\title{
DINAMIKA TAFSIR SOSIAL INDONESIA
}

\author{
Sunarto \\ Institut PTIQ Jakarta \\ sunarto@gmail.com
}

\begin{abstract}
ABSTRAK
Al-Qur'an adalah kitab suci yang diturunkan oleh Yang Maha Suci. Agar kesucian alQur'an lebih bermakna dan relevan dengan tujuan diturunkannya al-Qur'an (sebagai petunjuk bagi kehidupan manusia, sebagai pembeda yang haq dengan yang bathil), maka al-Qur'an perlu direfleksikan ke dalam dunia nyata. Dengan hadirnya model "Tafsir Sosial" ini merupakan langkah maju yang perlu diapresisi, atas keberanian mufassir/penulis dalam menganulir ayat-ayat al-Qur'an tidak sebatas pemahaman teks-teks ayat al-Qur'an semata, melainkan mufassir mengaktualisasikan ayat-ayat alQur'an dengan problem perkembangan sisial politik masyarakat yang sedang terjadi. Boleh jadi pada masa tertentu ketajaman pena penulis berhadapan dengan ujung pedang Sang Penguasa. Disinilah letak uji nyali penulis/ mufassir dalam menuangkan buah pikirannya.
\end{abstract}

Kata kunci: Tafsir, social, al-Qur'an, suci, aktualisasi.

\begin{abstract}
The Qur'an is a holy book that revealed by the Most Holy. In order for the sanctity of the Qur'an to be more meaningful and relevant to (as a guide for human life, as a distinguishing between the true and the false), the Qur'an needs to be reflected in the real world.

With the presence of "Social Interpretation" model, this is a step forward that needs to be appreciated, as the courage of the mufassir in annuling the Qur'an is not limited to understanding Qur'an, but rather the mufassir actualizes the Qur'an with problems of social political development. Sometimes writing point of the writer is faced with the tip of the Lord's sword. Therein the test mufassir's guts in pouring his thoughts.
\end{abstract}

Keywords: Interpretation, social, al-Qur'an, holy, actualization 


\section{Pendahuluan}

Muhammad Abduh dalam tafsir al-Manarnya berkata, "Pada hari akhir nanti, Allah tidak akan bertanya kepada kita mengenai pendapat-pendapat para mufassir dan tentang bagaimana mereka memahami al-Qur'an, tetapi Allah akan bertanya kepada kita tentang kitab-Nya yang Ia wahyukan untuk membimbing dan mengatur kita."1

Dalam pandangan Abduh, al-Qur'an yang diturunkan kepada manusia kurang relevan dengan pesan-pesan Allah itu sendiri (sebagai petunjuk jalan kepada manusia). Al-Qur'an terkesan lebih eksklusif yang bisa difahami oleh kalangan elit tertentu saja, sehingga kurang terbuka (tidak bisa dikonsumsi) oleh kalangan awam/ umum.

Agar dapat membumikan kandungan al-Qur'an terhadap masyarakat, tentu perlu adanya gerakan aktualisasi interpretasi ayat-ayat al-Qur'an terhadap problematika kekinian yang terjadi di masyarakat. Sehingga pemahaman tafsir tidak terkobtip ke dalam pemahaman ayat-ayat tekstual saja, melainkan mufasir bisa membawa pemahaman makna/ ruh al-Qur'an ke dalam dunia sosial, politik dan problem kehidupan real masyarakat. Model pemikiran inilah yang mengilhami munculnya penafsiran tafsir sosial.

Al-Qur'an bisa dikemas dengan bahasa yang lebih praktis, menarik (sesuai dengan bahasa kaumnya/ بقر عقولها), agar masyarakat awam tidak lagi mengerutkan keningnya ketika membaca kitab-kitab tafsir. Lebih jauh, Abduh menginginkan agar tafsir bisa mengembalikan fungsi al-Qur'an sebagai kitab petunjuk (hudan li alnas). ${ }^{2}$ Artinya, dalam memaknai al-Qur'an, tafsir harus memposisikan al-Qur'an sebagai kitab yang 'hidup'. Kitab yang selalu memberikan petunjuk kepada pembacanya dalam menyelesaikan problem hidup keseharian. Tidak sebaliknya, alQur'an memposisikan sebagai kitab yang 'mati,' sehingga al-Qur'an dikesankan diam seribu bahasa, ketika pembacanya ditimpa berbagai permasalahan hidup. Meminjam perkataan Nurcholish Madjid, harus ada dimensi / unsur kemanusiaannya dalam usaha memahami ajaran agama, dalam hal ini memahami al-Qur'an. ${ }^{3}$

Dalam bahasa yang lebih menarik, Dr. Abdul Majid Abdussalam al-Muhtasib mengatakan, "Meng-hermeneutikasi-kan dan mengeluarkannya (al-Qur'an) dari tekstualitasnya agar selaras dengan fenomena-fenomena." Al-Muhtasib menginginkan al-Qur'an bisa keluar dari konteksnya dan berusaha memberi tanggapan terhadap fenomena yang ada di sekitarnya. Sehingga al-Qur'an tidak diam begitu saja ketika melihat fenomena di sekelilingnya. Tetapi al-Qur'an responsif dan tanggap dalam memecahkan problem sosial-kemasyarakatan. Belakangan ini, usahausaha tersebut sudah banyak dilakukan para ilmuwan muslim kontemporer, seperti Mohammed Arkoun, Hassan Hanafi, Fazlur Rahman, Farid Esack, atau Fatima

\footnotetext{
${ }^{1}$ Muhammad Rasyid Ridha, Tafsir al-Qur'an al-Hakim al-Mushtahir bi Tafsir al-Manar, Jilid I, Kairo 1954-1961, 26, seperti dikutip oleh J. J. G. Jansen, Diskursus Tafsir al-Qur'an Modern, terj. Hairussalim, dkk. (Yogyakarta: Tiara Wacana, 1997), 28.

${ }^{2}$ Abdul Mustaqim, Madzahibut Tafsir: Peta Metodologi Penafsiran al-Qur'an Periode Klasik hingga Kontemporer (Yogyakarta: Nun Pustaka, 2003), 93.

${ }^{3}$ Nurcholish Madjid, Islam Doktrin dan Peradaban: Sebuah Telaah Kritis tentang Masalah Keimanan, Kemanusiaan, dan Kemodernan (Jakarta: Paramadina, 2000), 329.

${ }^{4}$ Abdul Majid Abdussalam al-Muhtasib, Visi dan Paradigma Tafsir al-Qur'an Kontemporer, terj. Moh. Maghfur Wachid (Bangil: al-Izzah, 1997), 279.
} 
Mernissi. ${ }^{5}$ Walaupun usaha-usaha mereka masih banyak dinafikan oleh para ulama tradisionalis yang masih mengedepankan dimensi tekstualitas al-Qur'an.

Menurut hemat penulis belum ada perkembangan secara segnifikan terkait dengan tafsir sosial Indonesia. Baru pada periode abad ke XX an mulai bermunculan karya-karya tafsir sosial secara kondisional memberikan kritik sosial, politik dan kemanusiaan.

Melihat urgensinya problematika tersebut, di sini penulis memberikan batasan permasalahan terkait: Kajian teoritis Tafsir Sosial yang berkembang di Indonesia, dengan Rumusan Permasalahan sebagai berikut:

Bagaiamana Dinamika Tafsir Sosial di Indonesia?

\section{Kajian Pustaka}

Untuk menjawab rumusan masalah di atas, marilah kita melihat sejenak beberapa kitab tafsir yang lahir dari rahim Ibu Pertiwi Nusantara. ${ }^{6}$ Dalam membahas dinamika tafsir Indonesia, penulis lebih menyandarkan pada periodisasi kitab tafsir Indonesia Indal Abror. ${ }^{7}$ Selain periodisasi yang dibuat lebih menyeluruh, juga penyajiaanya yang penulis kira cukup rinci dan jeli.

Periodesasi perkembangan tafsir di Indonesia dapat ditinjau melalui beberapa tahapan sebagai berikut:

Pada periode abad VII atau abad VIII-XV M. di Nusantara belum muncul kitab-kitab tafsir secara spesifik sebagai disiplin ilmu. Hal ini disebabkan karena masih bersatunya beberapa dimensi ajaran Islam, seperti syari'ah, ibadah, dan aqidah. Dengan kata lain, masih belum jelasnya pembedaan beberapa dimensi ajaran Islam. Hal ini disebabkan karena agama Islam baru menyentuh bumi Nusantara. Sehingga konsentrasi mereka masih terpusat pada pengamalan ajaran Islam semata. Belum merambah kepada keinginan mengkaji ajaran Islam secara lebih serius.

Baru pada periode abad XVI-XVIII M, sudah mulai terlihat geliat umat Islam Nusantara dalam mengkaji ajaran Islam, khususnya ilmu tafsir. Hal ini bisa dilihat dengan munculnya tafsir karya Abdur Rauf Ali al-Fansuri atau al-Sinkili. Kitab tafsir ini diberi judul "Tarjuman al-Mustafid". Kitab tafsir yang merupakan salinan dari kitab Anwar al-Tanzil wa Asrar al-Ta'wil, ada juga yang mengatakan terjemah dari tafsir al-Jalalain, ini adalah kitab tafsir pertama di Indonesia. Namun menurut kajian yang dilakukan Ishlah Gusmian, tafsir yang pertama kali muncul justru Tafsir Surah al-Kahfi [18]: 9. Tafsir yang tidak diketahui penulisnya ini muncul lebih awal dari tafsir Tarjuman al-Mustafid, yang muncul pada abad XVII. Sementara tafsir surat alKahfi sendiri muncul pada abad XVI. ${ }^{8}$

Pada periode selanjutnya, abad XIX M, muncul ulama kenamaan asal Banten, Imam Muhammad Nawawi al-Bantani (1230 H/ 1813 M - 1314 H/ 1897 M.). Imam

5 Untuk mengetahui lebih detail corak penafsiran para ilmuwan muslim kontemporer, lihat Abdul Mustaqim dan Syahiron Syamsudin (Ed.), Studi al-Qur'an Kontemporer: Wacana Baru Berbagai Metodologi Tafsir (Yogyakarta: Tiara Wacana, 2002).

${ }^{6}$ Untuk mengetahui perkembangan tafsir di wilayah Nusantara ini, bisa dilihat beberapa karya ilmiah yang membahas masalah tersebut. Di antaranya Howard M. Federspiel, Kajian al-Qur'an di Indonesia: dari Mahmud Yunus hingga Quraish Shihab, terj. Drs. Tajul Arifin, MA.,Bandung: Mizan, 1996, Islah Gusmian, Khazanah Tafsir Indonesia: dari Hermeneutika hingga Ideologi, Jakarta: Teraju, 2003, dan Indal Abror, "Potret Kronologis Tafsir Indonesia”, ESENSIA, Vol. 3, No. 2, Juli 2002, hal. 189-200.

${ }^{7}$ Indal Abror, "Potret Kronologis", hal. 189-200.

${ }^{8}$ Islah Gusmian, Khazanah Tafsir, hal. 53. 
Nawawi menulis sebuah karya tafsir yang cukup monumental. Karya beliau ini berjudul Marah Labid atau lebih dikenal Tafsir Munir li Ma'alim al-Tanzil.

Sejak periode abad XX M sampai sekarang, bermunculanlah beragam kitab tafsir yang ditulis ulama Indonesia dengan berbagai coraknya. Dalam hal ini, Indal Abror membaginya ke dalam tiga periode. ${ }^{9}$

Periode pertama, awal abad XIX M sampai tahun 1950-an. Pada periode ini, tafsir ditulis dengan menggunakan metode ijmali (global) atau tarjamah tafsiriyah (tarjamah maknawi). Di antara karya tafsir yang muncul pada periode ini adalah al-Furqan, yang ditulis oleh A. Hassan. Penulisan kitab tafsir ini dimulai tahun 1928, dan selesai tahun 1956. Selain itu, pada tahun 1937 muncul Tafsir al-Qur'an Karim. Tafsir yang ditulis oleh H. A. Halim Hassan, H. Zainal Arifin Abbas, dan Abdurrahman Haitami ini pada mulanya ditulis dalam bentuk majalah 20 halaman, yang terbit tiap bulan. Kedua karya tafsir ini sangat lekat diwarnai oleh kepentingan madzhab. Selain kedua karya tafsir ini, muncul Tafsir Qur'an Indonesia yang diterbitkan oleh Muhammadiyyah. Karya tafsir yang muncul pada tahun 1932 ini cenderung netral, tidak diwarnai kepentingan madzhab tertentu, seperti dua karya tafsir di atas.

Periode selanjutnya, 1951-1980, karya tafsir Indonesia, dalam penulisannya, memakai metode tahlili (detail). Pada periode ini muncul tafsir yang cukup monumental, yaitu Tafsir al-Azhar. Tafsir yang masih populer sampai saat ini, ditulis oleh Hamka. Tafsir ini ditulis pada saat suasana politik tidak menentu, dimana bahaya komunis sedang marak. Sehingga, karya ini banyak memberikan arahan kepada pembacanya dalam menghadapi aneka permasalahan yang terjadi saat itu.

Pada periode tahun 1980-an sampai tahun 2000, sudah makin banyak karya tafsir yang bermunculan. Pada periode ini, penulis tafsir cenderung memakai metode maudlu'i (tematik) dalam menulis karyanya. Di antara karya tafsir pada periode ini adalah tafsir yang ditulis M. Quraish Shihab, yaitu Wawasan al-Qur'an. Secara agak komprehensif, tafsir ini membahas beragam permasalahan yang dihadapi oleh masyarakat.

Berbagai perkembangan tafsir Indonesia tersebut, menurut hemat penulis, masih sedikit tafsir yang ditulis dengan menyertakan dimensi sosial-kemasyarakatan. Apalagi tafsir yang muncul sebelum dekade 1950-an. Setelah periode ini, sudah mulai ada kitab tafsir yang memasukkan dimensi sosial tersebut. Hal ini bisa dilihat dari Tafsir al-Azhar. Selanjutnya, karya tafsir yang lebih banyak mengulas dimensi sosial adalah tafsir yang muncul setelah dekade 1990-an. ${ }^{10}$ Dalam kajian Islah Gusmian, ada 24 karya tafsir yang muncul pada perode tersebut. Walaupun tidak semuanya, karya tafsir yang banyak memakai metode maudlu'i ini, sudah menunjukkan kecenderungan untuk memasukkan dimensi sosial dalam karya tafsirnya. Dari 24 karya tafsir tersebut di ataranya Ensiklopedi al-Qur'an: Tafsir Sosial Berdasarkan Konsep-konsep Kunci, karya Prof. M. Dawam Rahardjo, Wawasan al-Qur'an: Tafsir Maudlu'i Pelbagai Persoalan Umat karya Dr. M. Quraish Shihab, MA., Argumen Kesetaraan Gender: Perspektif al-Qur'an, karya

${ }^{9}$ Sebagai perbandingan, lihat juga periodisasi literatur tafsir di Indonesia yang dibuat Islah Gusmian. Islah Gusmian, dalam kajiannya membagi karya tafsir di Indonesia ke dalam dua periode. Periode antara awal abad ke-20 hingga tahun 1960-an dan periode antara tahun 1970-an hingga tahun 1980-an. Walaupun pada kajian selanjutnya, Gusmian menambahkan tafsir yang muncul pada dekade tahun 1990-an.

${ }^{10}$ Islah Gusmian, Khazanah Tafsir, 69-99. 
Dr. Nasaruddin Umar, MA., Dalam Cahaya al-Qur'an: Tafsir Sosial Politik alQur'an karya Syu'bah Asa, dsb.

\section{PEMBAHASAN}

\section{Membangun Dimensi Tafsir Sosial Indonesia}

Melihat kondisi tafsir Indonesia di atas, penulis berkesimpulan, al-Qur'an masih belum memberikan solusi terhadap para pembacanya. Hal ini bisa dilihat dari masih banyaknya karya tafsir di Indonesia yang mengabaikan dimensi sosialkemasyarakatan. Sehingga karya tafsir hanyalah akumulasi dari paham keagamaan semata. Padahal sejatinya, al-Qur'an, melalui tafsirnya, harus mampu memberikan jalan keluar atau solusi terhadap permasalahan yang dihadapi umatnya.

Mungkinkah menyusun karya tafsir yang banyak mengakomodasi dimensi sosial, dengan kata lain, mungkinkah menulis karya tafsir yang solutif terhadap kondisi umat? Tidak mudah menjawab pertanyaan ini. Selain karena masih membudayanya kajian al-Qur'an yang hanya menekankan tekstualitasnya saja, juga masih banyaknya umat Islam yang kurang menguasai ilmu-ilmu sosial, yang notabene diperlukan untuk menghubungkan al-Qur'an dengan dimensi sosial. Walau demikian, jalan ke arah pembentukan dimensi sosial tafsir Indonesia masih terbuka. Dengan merujuk pada al-Manhaj al-Ijtima 'i fi al-Tafsir yang digagas Hassan Hanafi, ${ }^{11}$ penulis ingin menawarkan beberapa konsep dasar membangun tafsir Indonesia yang berdimensi sosial.

Pertama, dalam menafsirkan al-Qur'an, seorang penafsir hendaknya tidak berangkat dari ruang kosong. Dalam arti, penafsiran berangkat dari kondisi realitas yang membutuhkan solusi. Dalam hal ini, metode induktif lebih cocok digunakan. Karena metode ini berangkat dari kasus-kasus untuk kemudian mencari kesimpulan. Demikian juga tafsir, berawal dari kondisi sosial, dengan berlandaskan al-Qur'an, ditarik sebuah makna yang solutif.

Kedua, dengan begitu, tentu harus ditetapkan tujuan yang jelas dari penafsiran. Seperti sudah ditekankan di atas, tujuan ini tentunya mencari solusi bagi problem sosial yang dihadapi umat.

Ketiga, penelusuran terhadap ayat-ayat al-Qur'an yang dilakukan tentu bukanlah pemaknaan yang parsial dan dangkal. Penelusuran ini harus diarahkan kepada pencarian world view al-Qur'an. Dengan begitu, pesan utama al-Qur'an bisa kita raih.

Keempat, penafsiran yang dibangun haruslah sebuah penafsiran yang transformatif. Artinya, pemahaman terhadap al-Qur'an adalah pemahaman yang hidup dan menggerakkan. Bukan pemahaman yang mati dan beku. Sehingga, penafsiran bisa membawa dampak besar dalam perubahan dan perjalanan sejarah.

Pada uraian berikutnya, penulis akan mendeskripsikan lebih detail lagi contohcontoh tafsir sosial politik "Dalam Cahaya al-Qur'an: Tafsir Sosial Politik alQur'an" karya Syu'bah Asa.

\section{Kritik Tafsir Sosial Syu'bah Terhadap Pemerintahan Orde Baru}

Syubah $^{12}$ adalah seorang wartawan dan Budayawan penulis tafsir social yang berjudul " Dalam Cahaya al-Qur'an: Tafsir Ayat-ayat Sosial Politik". ${ }^{13}$

${ }^{11}$ M. Mansur, "Metodologi Tafsir Realis: Telaah Kritis terhadap Pemikiran Hassan Hanafi”, dalam Abdul Mustaqim dan Sahiron Syamsudin (Ed.), Studi al-Qur'an, 104-107.

12 Syu'bah Asa lahir di kota batik, Pekalongan 21 Desember 1941. Syu'bah di lahirkan dari keluarga relegius penghafal al-Qur'an desa Kerandan, Pekalongan Selatan. Ayahnya seorang pengusaha batik di kota tersebut. Setelah menyelesaikan pendidikan di Madrasah Aliyah, Syu'bah 
Pada era tahun 1950-1969, Syu'bah dikenal sebagai seniman dan aktif di teater muslim bengkel teater Yogyakarta. Pada tahun 1970 ia menjadi Dewan Kesenian Jakarta. Di tahun-tahun berikutnya ia berkarir sebagai wartawan. Mulai di Espres (cikal bakal majalah Tempo), sebagai redaktur music pada tahun 1970. Sejak berdirinya majalah Tempo, ia merupakan penulis kritik teater yang paling tajam secara kontinyu. Setelah keluar dari majalah Tempo tahu 1987, ia diangkat menjadi ketua siding majalah Editor, lalu berpindah menjadi wakil pimpinan redaksi Harian Pelita. Diujung karir wartawannya ia bekerja di majalah Panji Masyarakat. Di majalah Panji Masyarakat inilah ia menulis tafsir social berjudul, "Dalam Cahaya al-Qur'an: Tafsir Ayat-ayat Sosial Politik", tepat diujung akhir kekuasaan rezim orde Baru. Syu'bah mengembuskan nafas terakhir di Rumah Sakit Islam Muhammadiyah, Pekajangan Pekalongan Jawa Tengah Ahad, 24 Juli 2011, pukul 17:00 WIB pada usia 70 tahun. ${ }^{14}$

Tafsir "Dalam Cahaya al-Qur'an, Tafsir Ayat-ayat Sosial Politik" pada awalnya ditulis oleh Syu'bah sebagai artikel tafsir di majalah Panji Masyarakat secara serial setiap edise. Pada tahun 2000 artikel-artikel tersebut dikumpulkan, diedit ulang oleh penerbit PT. Gramedia Pustaka Utama Jakarta. Pada edise cetakan pertama buku ini diberi kata pengantar oleh Kuntowijoyo (seorang sahabat karibnya). Tebal buku ini mencapai 482 halaman dengan 21 halaman romawi. Dilihat dari data yang disertakan di setiap akhir tulisan, tulisan-tulisan tersebut dibuat dalam rentang waktu 19971999.

Di dalam tafsirnya disamping menganalisa teks al-Qur'an, Syubah juga melakukan kontestasi dan kajian kritis atas realitas social politik yang terjadi pada saat tafsir tersebut ditulis dengan mendialektikakan pada subtansi pesan-pesan Tuhan yang terkandung dalam al-Qur'an, yang tidak hanya sekedar memahami teks-teks alQur'an saja, melainkan sekaligus mengkorelasikan dengan situai dan kondisi perpolitikan yang sedang terjadi. Sehingga pemikiran tersebut dapat menambah perkembangan perbendaharaan khazanah wacana tafsir yang berkembang di Indonesia.

Secara Umum, ada empat topik utama yang dibicarakan Syu'bah dalam tafsirnya, yaitu terkait dengan masalah penegakan keadilan, pelangaran HAM, praktik korupsi, dan praktik keberagamaan yang sebatas gincu. Empat topik itu dipilih dalam tulisan ini karena terkait erat dengan problem sosial politik yang terjadi di era rezim Orde Baru. Topik-topik ini oleh Syu'bah dijadikan arena untuk menggerakkan kritik sosialnya dan mengkontestasikannya dalam ruang publik yang pada era itu berhadapan langsung dengan kekuatan hegemoni dan dominasi rezim Orde Baru. Uraian berikut adalah tentang keempat topik tersebut.

\section{a. Penegasan Keadilan}

Sebagai salah satu bendera gerakan reformasi di penghujung kekuasaan rezim Orde Baru, isu penegakan keadilan diangkat tinggi-tinggi oleh para aktivis, LSM, wartawan, intelektual dan agamawan. Hal ini disadari penting, karena ketika itu penegakan keadilan terasa tumpul ketika berhadapan dengan dengan pejabat dan penguasa. Syu'bah membicarakan tema keadilan ini dalam lima artikel tafsir, yaitu: "Keadilan dan Kesaksian Allah", "Apa yang disebut adil", "Keadilan atau

melanjutkan kuliah di IAIN Sunan Kalijaga Jogjakarta sembari belajar privat kitab kuning dengan seorang Kiyai di Lempuyangan. Syu'bah pernah nyantri kalong di ponpes Kraprak Yogyakarta.

${ }^{13}$ Islah Gusmian, Tafsir al-Qur'an dan Kritik Sosial: Syu'bah Asa Dalam Dinamika Tafsir alQur'an di Indonesia, dalam Maghza Vol. 1, No. 2, Juli-Desember 2016. hal.68.

14 “Jenazah Syu'bah di Makamkan”, dalam Tempo Interaktif Pekalongan, edise 25 Juli 2011. 
Kehancuran", "Keadilan dan Kebencian", dan "Keadilan dan Mantan Presiden". Hal ini menunjukkan, bahwa Syu'bah menaruh perhatian serius terkait masalah penegakan keadilan ini.

Ketika masalah topik keadilan didiskusikan dalam konteks wacana teologi klasik, selalu yang muncul adalah diskusi mengenai keadilan Tuhan, bukan keadilan manusia di bumi. Sebagai umat beriman, tanpa berdiskusi yang melelahkan, kita sangat mudah untuk mengatakan bahwa Allah adalah Sang Maha Adil. Hal yang menjadi penting adalah apa dan bagaimana keadilan itu menjadi hidup dan bisa dirasakan dalam kehidupan umat manusia di bumi.

Di sinilah kemudian Syu'bah menarik masalah keadilan ke konteks kehidupan real. Ia menjelaskan tentang "Apa yang disebut adil" ketika mengulas kandungan QS.Al-Nahl [16]: 90.

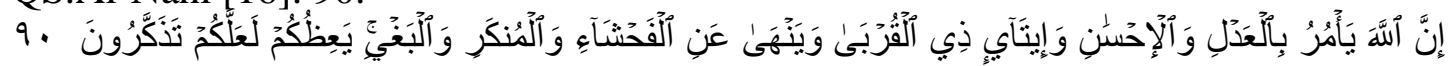

[ النحل:90]

Sesungguhnya Allah menyuruh (kamu) berlaku adil dan berbuat kebajikan, memberi kepada kaum kerabat, dan Allah melarang dari perbuatan keji, kemungkaran dan permusuhan. Dia memberi pengajaran kepadamu agar kamu dapat mengambil pelajaran. [An Nahl:90]

Syu'bah, mengartikan ayat tersebut dengan, "Sesungguhnya Allah memerintahkan sikap adil dan kebajikan dan pemberian bantuan kepada karib kerabat, serta mencegah perbuatan keji dan kemungkaran dan laku angkara. Ia mewejang kamu agar kamu mengingat-ingat".

Bagi Syu'bah keadilan merupakan masalah utama di dalam kehidupan umat manusia. Dengan mengutip Plato, ia menyatakan bahwa banyak syarat yang mesti di penuhi oleh seorang pemimpin negara yang akan mengawal keadilan. Merekalah, dengan kekuasaannya, yang akan mengelola pemerintahan. Mereka selayaknya merupakan pribadi-pribadi yang berada dalam cahaya akal budi ${ }^{15}$, sehingga menegakkan keadilan bukan atas kebencian atas golongan, suku ras dan agama. Dari arah ini, Syu'bah mulai mengkritik praktik politik rezim Orde Baru yang mempermainkan keadilan, karena kebencian dan kepentingan golongan. Dengan tegas dan lugas dalam Dalam Cahaya Al-Qur'an Syu'bah menulis:

....bagaimanakah keadilan dipegang di tengah kemungkinan rasa benci dalam berbagai kasus? Misalnya, apakah memang Soeharto punya sedikit peranan, paling tidak pengetahuan sebelumnya, dalam meletusnya G.30 S. PKI? Pertanyaan ini dulu juga ditujukan kepada Bung Karno. Apakah, terus terang saja, kudeta itu tanggung jawab PKI sebagai partai, dilakukan hanya oleh satu sayapnya, atau atas nama perorangan? Pertanyaan ini dulu juga diajukan sehubung dengan peranan Masyumi dalam pemberontakan PRRI. Apakah demi demokrasi kita harus memberi tempat kepada kekuatan anti demokrasi? Apakah peranan Benny Moerdani dan TrI Sutrisno dalam kasus Tanjung Priok, misalnya, dan peranan Soeharto dan/ atau satu-dua tokoh puncak lain dalam peristiwa penculikan para aktivis 1990? Bagaimana pula dengan penembakan mahasiswa Trisakti? ${ }^{16}$

\section{b. Kekuasaan dan Pelanggaran HAM} 2000), 358

${ }^{15}$ Syu'bah Asa, Dalam Cahaya al-Qur'an: Tafsir Ayat-ayat Sosial Politik (Jakrta: Gramedia,

${ }^{16}$ Syu'bah Asa, Dalam Cahaya al-Qur'an, 366. 
Topik kedua yang dibicarakan Syu'bah adalah soal hegemoni dan dominasi kekuasaan rezim Orde Baru yang melahirkan kekerasan dan pelanggaran HAM. Atas nama stabilitas sosial politik, rezim Orde Baru di bawah kendali Soeharto mengebiri kekuatan-kekuatan politik, baik yang dikaitkan dengan PKI ataupun kekuatankekuatan politik yang saat itu dianggap mengganggu bagi eksistensi kekuasaannya. Ketika menjelaskan kandungan QS. Al-An'am [6]:65

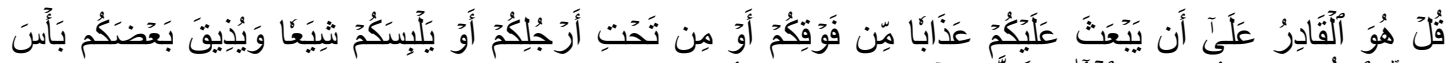

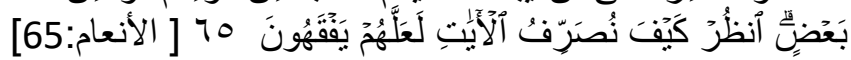

Katakanlah: "Dialah yang berkuasa untuk mengirimkan azab kepadamu, dari atas kamu atau dari bawah kakimu atau Dia mencampurkan kamu dalam golongangolongan (yang saling bertentangan) dan merasakan kepada sebahagian kamu keganasan sebahagian yang lain. Perhatikanlah, betapa Kami mendatangkan tandatanda kebesaran Kami silih berganti agar mereka memahami(nya)". [Al An'am:65]

Misalnya, sikap kritis Syu'bah tampak kuat dan lugas.

Katakanlah, "Dialah yang berkuasa mengirim kepada kamu hukuman dari atas kamu dan dari bawah kamu, atau mengacaukan kamu dengan situasi bersyi'ah-syi'ah dan membuat sebagian kamu merasakan keganasan sebagian yang lain. "Lihatlah, bagaimana Kami petukarkan berbagai tanda agar mereka paham.

Ayat ini berbicara tentang hukuman atas siksa Allah yang ditimpahkan kepada umat manusia yang melakukan pembangkangan. Allah menurunkan hukuman itu dari atas, dari bawah, atau dengan mengacaukan mereka dengan situasi social berceraiberai, sehingga mereka saling melakukan anarkis. Konteks ayat ini lalu bi bawah Syu'bah ke dalam ruang keindonesiaan:

Seperti keganasan yang dulu dialami sebagai buah manuver Partai Komunis Indonesia (PKI), khususnya menjelang kejatuhan Soekarno (pemberangusan, tudingan "kontrorevolusi", fitnah, pemecatan, penutupan peluang kerja, pengkeroyokan, penjeblosan ke BUI (penjara) tanpa proses, penyiksaan), dan akhirnya keganasan lebih besar yang diterima PKI setelah kudeta gagal, dengan banyak sekali terseret korban orang-orang tak berdosa atau yang ikut-ikutan, yang terkadang tampak sebagai bayangan gerak takdir yang menebarkan kesediahan. Sampai kini. ${ }^{17}$

Syu'bah mengingatkan kita, bahwa rezim Orde Baru telah melakukan praktek politik yang tidak selaras dengan Hak Asasi Manusia. Ribuan orang sengaja tidak diberi kesempatan untuk bekerja di birokrasi pemerintah, karena dianggap tidak bersih lingkungan, alias orang tua, saudara, atau kerabatnya pernah menjadi aktivis atau setidaknya menjadi simpatisan Partai Komunis Indonesia, yang diklaim berdosa terhadap kedaulatan Negara, yang telah mencaba melakukan kudeta pada tanggal 1 Oktober 1965. Hal ini masih beruntung tidak dibuang ke pulau Buru atau dijebloskan ke penjara tanpa adanya proses hukum yang jelas.

\section{c. Praktik Korupsi di Tubuh Birokrasi}

Birokrasi yang gemuk dan tidak efisien yang dibangun oleh rezim Orde Baru telah membuka lahan subur praktik korupsi. Ketika menguraikan QS. Al-Nisa' [4]: 135 "Wahai orang-orang beriman, jadilah kamu para penegak keadilan sebagai saksi Allah, walau terhadap diri sendiri atau kedua orang tua dan sanak kerabat," ayat yang

\footnotetext{
${ }^{17}$ Syu'bah Asa, Dalam Cahaya al-Qur'an..., hal. 173.
} 
berbicara tentang penegakan keadilan,Syu'bah mengaitkannya dengan kasus-kasus korupsi yang melibatkan para pejabat tinggi di era rezim Orde Baru. Dengan nada menyindir Syu'bah menulis dalam tafsirnya:

Padahal, berapa gaji seorang presiden? Punyakah dia perusahaan? Ke manakah, sekali lagi, dana yayasan-yayasan di bawah dia? Atau seperti yang dicontohkan Abdul Hakim Garuda Nusantara, apakah sikap kerasnya untuk memberikan fasilitas buat mobil nasional (Timor), dengan memanfaatkan Negara, tergolong atau tidak tergolong korupsi? Juga, misalnya, Keppes tentang penggunaan dan reboisasi untuk IPTN? Masalahnya jadi tidak sederhana. Presiden berhak mengeluarkan Keppes. Sementara itu lebih dari 50 Keppes, seperti ditemukan lembaga pimpinan Mar'ie Muhammad, dibuat dangan indikasi kepentingan Soeharto, keluarga, dan kawan-kawan. ${ }^{18}$

Kasus-kasus korupsi tersebut terjadi slingkait berkelindan dengan praktikpraktik suap yang melibatkan para pejabat, dari kelurahan hingga jajaran menteri. Syu'bah dengan transparan mengurai kasus suap ini ketika menafsirkan ayat tentang kewajiban berpuasa di bulan Ramadhan (QS. Al-Baqarah [2]: 183), yang menurutnya sebagai pusdiklat yang melahirkan sifat amarah. Dengan nada sarkastis Syu'bah menulis:

Lihatlah: untuk bisa mendapat pekerjaan di instansi mana pun, termasuk menjadi guru, juga guru agama, diperlukan sogok! Juga untuk naik pangkat atau jabatan! Juga untuk menyelesaikan kasus anak yang ditabrak lari! Untuk "mengimbangi' pihak yang merampas harta kita, yang sudah lebih dulu memberi sogok! Untuk bisa mendapat KTP tepat waktu, atau surat izin yang menyangkut suatu usaha, atau keterangan bebas! Bahkan untuk bisa mendapat tiket kereta api kelas "eksekutif", di sebuah kota kabupaten $<$ khususnya di hari-hari libur, yang selalu sudah disediakan untuk orang-orang kaya "langganan". ${ }^{19}$

Praktik korupsi dan suap tersebut terkait erat dengan sistem perekonomian yang di bangun rezim Orba ketika itu. Pertumbuhan ekonomi lebih sering di tampilkan dengan hitungan angka-angka untuk menunjukkan peran pemerintah dalam membangun kesejahteraan rakyat, tetapi angka-angka itu sering kali tidak mewakili pertumbuhan ekonomi secara merata. Hal ini terjadi karena pertumbuhan ekonomi tidak identik dengan pemerataan ekonomi dan sistem perekonomian yang memusat yang di topang dengan praktik monopoli dan ekonomi perkoncoan serta kerabat yang di praktikan rezim Orde Baru.

\section{d. Redupnya Suara Moral Agamawan}

Dalam berbagai situasi sosial politik yang tidak menentu, dimana terabaikannya nilai-nilai keadilan dan kemanusiaan di Era Orde Baru, lantas muncul suatu pertanyaan, dimana suara moral Agamawan? Itulah pertanyaan lantang yang disampaikan Syu'bah dalam tafsir sosialnya. Ketika saluran resmi, seperti lembaga DPR, hukum telah dikooptasi oleh kekuasaan eksekutif, semestinya suara-suara agamawan dan aktivis demokrasi kemanusian berteriak bersama-sama menyuarakan untuk menegakkan keadilan dan kesejahteraan. Namun ruh agama melalui praktekpraktek rituanya pada era Orde Baru menurut Syu'bah justru terjebak pada ruang

\footnotetext{
${ }^{18}$ Syu'bah Asa, Dalam Cahaya al-Qur'an ..., hal. 373.

${ }^{19}$ Syu'bah Asa, Dalam Cahaya al-Qur'an..., hal. 83.
} 
simbolisme yang dipraktikkan oleh pemeluknya. Pandangan Syu'bah ini terlihat secara jelas ketika menfsirkan surat al-Anfal: 25 ia.menyindir para agamawan.

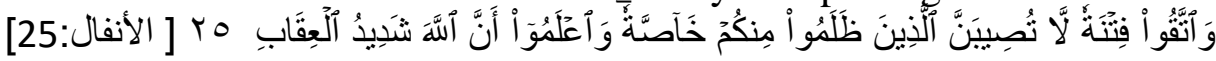

Dan peliharalah dirimu dari pada siksaan yang tidak khusus menimpa orang-orang yang zalim saja di antara kamu. Dan ketahuilah bahwa Allah amat keras siksaanNya. [Al Anfal:25].

Makna fitnah dan bencana pada ayat di atas menurut Syu'bah dijelaskan dalam kontek factor "sebab" dari meluasnya bencana yang dikatakan di atas, tidak hanya menimpa orang-orang yang aniaya saja. Memelihara diri sebagaimana yang dimaksud paya ayat tersebut merupakan kesadaran memelihara dari kemungkinan timbulnya fitnah dengan mewaspadai faktor-faktor yang bisa menjadi penyebab. ${ }^{20}$

Terkait dengan ini berbagai resepsi yang dilakukan oleh rezim orde baru menurut Syu'bah juga bagian dari bentuk ketidakmampuan umat beragama (Islam) didalam merefleksikan ruh agama dalam kehidupan sehari hari. Berbagai kegiatan ibadah ritual tidak mempunyai makna bagi kehidupan social. Disinilah kemudian Syu'bah kemudian mengkritik umat Islam:

Soalnya,memang cukup popular anggapan, bahwa puasa dan ibadah kita, bahkan secara umum naiknya pamor Isalm dari segi dakwah diperkotaan,yang di Indonesia mulai terasa dua dasawarsa lalu ,tidak punya hubungan apapuan dengan segala bentuk ketimpangan social di kalangan kita; korupsi, manipulasi, pungil, komisi tak halal, kolusi, monopoli, kebijaksanaan pilih kasih, nepotisme, penekanan, penggusuran tanpa imbalan wajar, rekayasa pengadilan, mafia peradilan, police brutality, sogok, sogok, sogok, ...

Lihatlah: untuk bisa mendapatkan pekerjaan di instasi manapun, termasuk juga menjadi guru, guru agama, diperlukan sogok! juga untuk naik pangkat atau jabatan! juga untuk menyelesaikan kasus anak yang ditabrak lari! Untuk "mengimbangi" pihak yang merampas harta kita ,yang sudah lebih dulu sogok! untuk bisa mendapat KTP tepat waktu, atau surat izin yang menyangkut suatu usaha, atau keterangan bebas! Bahkan untuk bisa mendapat tiket kereta api kelas "eksekutif",di sebuah kota kabupaten, khusus nya dihari-hari libur yang selalu sudah disediakan untuk orang-orang kaya "langganan"

Bahkan untuk dilayani baik ketika membayar pajak pun harus nyogok! Bahkan bantuan pembangunan masjid di potong dengan "persetujuan" panitia. Bahkan disekitar pemberangkatan jamaah haji mulai tercium aroma sogpk. Sementara itu kasus-kasus manipulasi dan perampasan tanah, dengan korban selalu merekayang lebih lemah, atau yang tak tahu "syarat permainan" (surat-surat dan sogok), terjadi dengan si perampas hak, yang dirampas haknya, calo tanahnya, lurahnya, camatnya, notarisnya, semuanya haji! Sogok, sogok, sogok! $!^{21}$

Bagi Syu'bah, sebagai agama Islam ideal nya dijadikan ruh dari gerakan kritik terhadap rezim yang otoriter dan menindas, namun dengan "cap Islam" ala Soeharto mendahului menelikung kesadaran para agamawan. Dalam kaitan ini Syu'bah kembali melakukan kritik, masih ketika menjelaskan ayat di atas:

Sama dengan ,semestinya, usaha menghalangi soeharto dari berbagai kebijaksanaan serupa, idealnya oleh para ulama yang di dalam kasus kita kemarin malahan lebih memilih "Cap Islam" yang diperagakan presiden dari pada keadilan social dan kebenaran. Padahal bukan isim, kata orang, tetapi musamma, bukan nama, yang mestinya dicari, tapi hakikat yang diberi nama. (tetapi seorang

\footnotetext{
${ }^{20}$ Syu'bah Asa, Dalam Cahaya al-Qur'an ..., hal. 200.
}

${ }^{21}$ Syu'bah Asa, Dalam Cahaya al-Qur'an ..., hal. 83. 
tokoh, yang kemudian menjadi menteri sebentar dalam kabinet terakhir soeharto, menyarankan kepada penulis ini: silakan "menyerang" siapa saja asal bukan Pak Harto, keluarganya dan "orang kesayangan"-nya.sebab, katanya, yang sekarang ini sudah bagus. Jangan sampai kita 'diseimbangkan' lagi dengan 'mereka' seperti zaman Benny Moerdani”). Dan terjadilah semua yang terjadi. Wallahu musta'an. ${ }^{22}$

Syu'bah dengan sejumlah pengalaman yang dimilikinya, bukan hanya mengkritrik otoriterisme rezim Soeharto saja, tetapi juga menunjukkan kepada kita betapa agama Islam ketika itu telah kehilangan peran penting justru di tangan pemeluknya sendiri. Agama sebagai system moral telah tercerabut di ruang social politik, yang semestinya mempunyai peran transformative dan signifikan bagi perubahan menuju Indonesia masa depan yang bermartabat, beradab dan berkeadilan.

\section{Tafsir al-Qur'an sebagai Praktis Kritik Sosial}

Uraian di atas mengarahkan pada satu kenyataan, bahwa Syu'bah dalam karya tafsirnya tersebut mengonstruksi Bahasa bukan sekadar sebagai alat komunikasi dalam menyampaikan gagasan, tetapi juga sebagai proses pewacanaan atas suatu peristiwa dan subjek-subjek yang berperan di dalamnya. Ia bergerak melakukan wacana perlawanan terhadap arus utama yang pada saat itu dibangun oleh Rezim Orde Baru.

Sebagai sebuah teks tafsir, Dalam Cahaya Al-Qur'an ini tidak hanya memaparkan proses pemaknaan pada teks-teks Al-Qur'an, lebih dari itu ia melakukan praktik kritik social dan pewacanaan yang sering kali berlawanan dengan wacana dominan yang dibangun dan didesakkan oleh rezim yang berkuasa untuk mengukuhkan status quo. Dengan demikian, praktik tafsir sebagaimana di tampilkan Syu'bah dalam karya tafsirnya ini, tidak sekadar menangkap gagasn Tuhan yang ada dalam teks-teks Al- Qur'an, tetapi juga meletakkan tafsir sebagai arena mengonstruksi sikap kritis dan perlawanan terhadap berbagai ketimpangan dan problem sosial politik yang terjadi di tengah masyarakat.

Strategi komunikasi yang dipakai Syu'bah Dalam Cahaya al-Qur'an ini terjadi karena sejumlah hal. Dari sudut subjek penafsir, tafsir ini ditulis oleh seorang wartawan, budayawan dan agamawan, yang inheren di dalamnya mempunyai sikap kritis terhadap berbagai penyimpangan yang terjadi. Dari sudut konteks situasi social dan ruang publikasi, tafsir ini mempunyai setidaknya dua momentum strategis. Pertama tafsir ini ditulis pada saat arus reformasi bergerak dengan kuat dan ujungnya pada Mei 1998 menghantam Rezim Orde Baru hingga jutuh. Kedua, Syu'bah menulis tafsir ini , awalnya di media massa yang ketika itu dunia pers mulai mengambil peran dalam melontarkan kritikan. majalah Panji Masyarakat dalam situasi ini berada dalam posisi pers yang kritis, sehingga Syu'bah diuntungkan dengan dua momentum tersebut ketika menulis tafsirnya.

Melalui tafsir Dalam Cahaya al-Qur'an, Syu'bah Asa menyadarkan kita, bahwa praktik penafsiran al-Qu'an sebaiknya memang diorentasikan ke dalam problem-problem social politik yang berkembang. Tafsir menjadi penting digerakkan ke arah kehidupan social. Orentasi tafsir tidak sekedar teosentris, teologis semata, malainkan tafsir bisa mengarah ke antroposentris dan ke dunia nyata dalam kehidupan. Problem-problem kemanusiaan dapat direfleksikan secara kritis, menteorisasikan dalam bentuk perubahan dan aksi. Ketika menguraikan masalah kemiskinan misalnya, penafsir tidak sekedar menggunakan logika kerohanian yang

22 Syu'bah Asa, Dalam Cahaya al-Qur'an, 204. 
dikaitkan dengan kwalitas keimanan yang rendah sebagai penyebabnya, melainkan kemiskinan dapat difahami dari berbagai factor social yang tengah menimpa masyarakat.

Syu'bah juga memberikan jalan, bahwa praktik tafsir dapat digerakan pada ruang yang spesifik dan historis, sehingga tafsir bisa lebih terasa dan bermakna terhadap perubahan kehidupan social, politik dan agama.

Sebagaimana yang tulis oleh Kontowijiyo dalam "Pengantar: al-Qur'an sebagai Kritik Sosial" dalam Cahaya al-Qur'an, bahwa model tafsir yang dilakukan Syu'bah Asa merupakan salah satu bentuk dari politisasi agama. Tetapi bila setiap bentuk kritik social politik pada ajaran agama disebut politisasi, maka agama atau alQur'an akan menjadi dokumen yang mati dan menjadi sekedar nomenklatur dan abstrak yang tidak ada korelasinya denga prilaku dan kehidupan kongkrit. ${ }^{23}$

\section{KESIMPULAN}

Sebelum munculnya dinamika tafsir-tafsir sosial secara spesifik, pertumbuhan tafsir-tafsir secara umum sudah mewarnai bumi pertiwi Indonesia dengan aneka metodologinya (ijmali, tahlili dan maudhu'i). Muncullah tafsir surat al-Kahfi abad 16 (tidak diketahu pengarangnya), tafsir "Tarjuman al-Mustafid" karya Abdur Rauf Ali al-Fansuri atau al-Sinkili (abad 17). Abad 19 Tafsir Munir li Ma'alim al-Tanzil (Marahu Labid) karya Imam Muhammad Nawawi al-Bantani (1230 H/ 1813 M 1316 H/ 1897 M.). Awal abad 19 tarjamah tafsiriyah (tarjamah maknawi) al-Furqan oleh A. Hassan tahun 1937, Tafsir al-Qur'an Karim oleh H. A. Halim Hassan, H. Zainal Arifin Abbas, dan Abdurrahman Haitami. Tafsir al-Azhar (tahun 1960-an) oleh Hamka tahun, Wawasan al-Qur'an (tahun 2000), Tafsir al-Misbah (th.2001) oleh M. Quraisy Shihab.

Tafsir berdimensi sosial baru muncul setelah dekade 1990-an. Diataranya Ensiklopedi al-Qur'an: Tafsir Sosial Berdasarkan Konsep-konsep Kunci, karya M. Dawam Rahardjo, Wawasan al-Qur'an oleh M. Quraish Shihab, Argumen Kesetaraan Gender: Perspektif al-Qur'an karya Nasaruddin Umar, Dalam Cahaya al-Qur'an: Tafsir Sosial Politik al-Qur'an karya Syu'bah Asa.

Di penghujung tumbangnya Orde Baru (abad 20) muncullah mufassir social modern Syu'bah Asa dalam karya monumentalnya "Dalam Cahaya al-Qur'an: Tafsir Ayat-ayat Sosial Politik". Mulanya tulisan tersebut dimuat dalam Majalah Panji Masyarakat secara berseri, selanjutnya diterbitkan oleh PT. Gramedia Pustaka Utama pada tahun 2000 dengan tebal 482 halaman, dengan kata pengantar Kuntowijoyo. Dalam tafsirnya, Syu'bah lebih mengkontekstualisasikan ayat-ayat al-Qur'an dengan fenomena sosial kemasyarakatan yang terjadi saat itu. Yaitu sifat otoriterisme, kesewenang-wenangan, pelanggaran HAM dan ketidakadilan yang dilakukan oleh rezim Orde Baru terhadap masyarakat, khususnya terhadap lawan politiknya.

\section{DAFTAR PUSTAKA}

${ }^{23}$ Kontowijoyo, "Pengantar: al-Qur'an sebagai Kritik Sosial” dalam Syu'bah Asa, Dalam Cahaya al-Qur'an, h. xii. 
Asa, Syu'bah, Dalam Cahaya al-Qur'an: Tafsir Ayat-ayat Sosial Politik, Jakarta: Gramedia, 2000.

Abdul.Mustaqim, Madzahibut Tafsir: Peta Metodologi Penafsiran al-Qur'an Periode Klasik hingga Kontemporer. Yogyakarta: Nun Pustaka, 2003.

Abdul Mustaqim, dan Syahiron Syamsudin (Ed.). Studi al-Qur'an Kontemporer: Wacana Baru Berbagai Metodologi Tafsir, Yogyakarta: Tiara Wacana, 2002.

Abror, Indal, "Potret Kronologis Tafsir Indonesia", ESENSIA, Vol. 3, No. 2, Juli 2002.

Esack, Farid, "Contemporary Religious Thought in South Africa and the Emergence of Qur'anic Heremeneutical Nation”, dalam ICMR, Vol.2, No.2, Desember 1991.

...........,al-Qur'an Liberation and Pluralism: An Islamic Perspective of Interrelegious Solidarity Againt Oppresion, Oxford: Oneworld, 1997.

Federspiel, Howard M, Kajian al-Qur'an di Indonesia: dari Mahmud Yunus hingga Quraish Shihab, terj. Drs. Tajul Arifin, MA. Bandung: Mizan, 1996.

Fadlillah, Arif, "Syu'bah Asa Tutup Usia" dalam Tempo edisi Minggu, 24 Juli 2011.

Gusmian, Islah, Tafsir al-Qur'an dan Kritik Sosial: Syu'bah Asa Dalam Dinamika Tafsir al-Qur'an di Indonesia, Maghza Vol. 1, N0.2, Juli-Desember 2016. .,Khazanah Tafsir Indonesia: dari Hermeneutika hingga Ideologi, Jakarta: Teraju, 2003.

HAMKA, Tafsir al-Azhar, Jakarta: Gema Insani Press, 2015.

Al- Jawi, Muhammad ibnu Umar Nawawi, Tafsir al-Munir/ Marahu Labid li Kasyfi Ma'na al-Qur'an al-Majid, Kairo: 1305 H/ 1888 M).

Jansen, J. J. G., Diskursus Tafsir al-Qur'an Modern, terj. Hairussalim, dkk., Yogyakarta: Tiara Wacana, 1997.

“Jenazah Syu'bah Asa dimakamkan”, dalam Tempo Interaktif Pekalongan, edise 25 Juli 2011.

Kontowijoyo, "Pengantar: al-Qur'an sebagai Kritik Sosial" dalam Syu'bah Asa, Dalam Cahaya al-Qur'an, h. xii.

Latif, Yudi, dan Ibrahim Ali Fauzi, "Polog" dalam Bahasa dan Kekuasaan, Politik Wacana di Panggung Orde Baru, Bandung: Mizan, 1996.

al-Muhtasib, Abdul Majid Abdussalam, Visi dan Paradigma Tafsir al-Qur'an Kontemporer, terj. Moh. Maghfur Wachid, Bangil: al-Izzah, 1997.

Madjid, Nurcholish. Islam Doktrin dan Peradaban: Sebuah Telaah Kritis tentang Masalah Keimanan, Kemanusiaan, dan Kemodernan. Jakarta: Paramadina, 2000.

M. Mansur, "Metodologi Tafsir Realis: Telaah Kritis terhadap Pemikiran Hassan Hanafi”, dalam Abdul Mustaqim dan Sahiron Syamsudin (Ed.), Studi alQur'an, hlm. 104 -107.

Pabotinggi, Moctar, "Komunikasi Politik dalam Pelaksanaan Pembangunan", Prisma, No. 6, Tahun XX, Juni 1991.

Ridha, Muhammad Rasyid, Tafsir al-Qur'an al-Hakim al-Mushtahir bi Tafsir alManar, Jilid I, Kairo 1954-1961.

Rubrik, "Tamu Kita”, dalam Majalah Kiblat, No. 59 Agustus 1991.

Shihab, Muhammad Quraisy, Tafsir al-Misbah, ( Jakarta: Lentera hati, 2001). 